\title{
Os Escolhidos da Técnica: a Difícil Arte de Ser "Viável"
}

EDLAINE DE CAMPOS GOMES •

\section{MENEZES, Rachel Aisengart \\ Dificeis decisões: etnografia de um Centro de Tratamento Intensivo Rio de Janeiro: Fiocruz, 2006}

O paciente ideal, além de "viável”, "responsivo",
"anônimo" e "cooperativo", é o indivíduo que por
suas características sociais e atributos pessoais, é
suficientemente próximo da equipe de modo a causar
certa empatia, possibilitadora de motivar seus
cuidados, e suficientemente distante para não produzir
na equipe uma identificação maior. (p. 73).

Este trecho está localizado no último capítulo do livro. Quando se chega nesta etapa da leitura, está-se quase sem fôlego.

Deparamo-nos o tempo todo com aquilo que não desejamos pensar: a possibilidade de em algum momento da vida passar pela experiência de um CTI; ou, em última instância, morrer. A autora torna públicas experiências críticas específicas de uma unidade hospitalar cercada de estigmas e liminaridade, sobretudo destacando as percepções daqueles que atuam diretamente no atendimento aos pacientes. O CTI, os profissionais das equipes, os pacientes, os profissionais externos e a pesquisadora compõem um cenário revelador das complexas relações sociais que envolvem as decisões sobre vida e morte no campo da medicina. É sobre o papel e as percepções dos profissionais intensivistas que a autora empreende seu trabalho etnográfico.

A autora enuncia o impacto do tema escolhido diante de seus pares. $\mathrm{O}$ risco de contaminação física era a principal preocupação daqueles que serviram de primeiros contatos para a entrada em campo: tabu de uma sociedade altamente 
medicalizada. O singular interesse de pesquisa da autora contrasta com essa percepção. Lidar/pesquisar situações dramáticas é uma barreira, seja para médicos, seja para antropólogos. Afinal, afastar-se dos doentes e dos moribundos é a tônica da sociedade moderna. Etnografar é o ofício do antropólogo, requer sensibilidade e, na maioria das vezes, enfrentar desafios. Os temas passíveis de estudo na perspectiva da antropologia das sociedades complexas são múltiplos. Abordar o complexo processo de decisões institucionalizadas acerca da vida e da morte por meio de observação participante mostra que os desafios se ampliam para a Antropologia na sociedade contemporânea.

Rachel Menezes apresenta, em sua análise, a complexa construção de identidade de uma especialidade médica - em fase de discussão à época da etnografia -, demarcação de fronteiras e status entre médicos e demais especialidades e pacientes, mas também ratifica a importância da pesquisa etnográfica. Identifica que, mesmo compartilhando da mesma categoria profissional - é médica e antropóloga -, as supostas facilidades de inserção em campo quase desaparecem pela própria ambigüidade de sua posição. Estava tão próxima, era tão "familiar", que para alguns era vista como uma avaliadora da técnica. A pesquisadora é vista dentro do contexto do CTI como alguém perigoso e também liminar. Pode ser a observadora, a avaliadora ou controladora das ações. "É o FBI", disse um dos observados.

Para o leigo, Centro de Tratamento Intensivo significa, em tensão, a emergência da morte e a esperança na possibilidade de se manter vivo. Para os intensivistas, é o local onde a morte é combatida e vencida pela técnica. Lugar apartado do mundo externo. Lugar de virtuosos: profissionais e pacientes. Os profissionais são ultra-especializados, dependentes da máquina e, paradoxalmente, de seus pacientes. O exercício da profissão é desgastante e condicionado à existência de instituição hospitalar. Outra característica significativa é o aparato tecnológico necessário ao exercício dos profissionais, sem o qual não seria possível o cuidado especializado do chamado "tratamento intensivo", assim como foi concebido originalmente.

São no máximo sete "doentes extremamente graves" os que podem ser atendidos no CTI analisado. É espantoso deparar-se com tal informação. É a liminaridade na liminaridade. Equipes completas, um "engarrafamento" de profissionais (médicos, estudantes de medicina, enfermeiros, auxiliares de enfermagem, fisioterapeutas, estudantes de fisioterapia, psicóloga, nutricionista, assistente social, entre outros), que se desdobram a cuidar daqueles que 
preconizam possuir "possibilidades terapêuticas". Seres "viáveis", quase extrahumanos, que além de "doentes" tornam-se co-responsáveis pela eficiência do cuidado intensivo. A luta é contra a liminaridade do paciente; pretende-se investir na vida, e não se deparar com a morte, por isto escolhe-se o viável.

O CTI é um lugar de passagem, visto antes como locus de purificação/ vida do que como de morte. Aquilo que combatem é, ao mesmo tempo, o que expõe sua fragilidade: a morte de um de seus "escolhidos". Neste caso, a morte é sempre considerada um fracasso, frustração maior do mundo medicalizado. A persistência de alguns pacientes também mostra os limites do poder e do conhecimento técnico. São os highlanders, aqueles que sobrevivem mesmo após a resolução de interromper os procedimentos intensivos para salvá-los.

O estado do indivíduo recebido para tratamento intensivo é ambíguo. Tem que estar em "estado grave", mas não tão grave a ponto de pôr em risco as certezas médicas, ou desperdiçar os meios médicos materiais e humanos. Após serem aceitos por "mérito", os escolhidos passam por avaliações físicas, psicológicas, comportamentais e morais. São alvos do cuidado e da eficácia da tecnologia que cerca o tratamento intensivo. São também objetos de estudo. A gravidade de sua situação infere maior interesse nos procedimentos e acompanhamento das decisões a serem tomadas. O risco e o trabalhar no limite são o cenário da dinâmica ensino-aprendizagem.

O próprio espaço utilizado para edificar a "equação competênciacuidado" possui atributos e estigmas específicos. O tempo é abolido para o paciente que é controlado e está sob constante vigilância. Perde-se a noção tanto de um como de outro $\mathrm{O}$ espaço é organizado para que as equipes possam ter o controle quase absoluto sobre os pacientes e procedimentos necessários ao cuidado eficiente. Afinal, o "viável" está em risco. O ritmo é intenso. Profissionais e pacientes convivem neste lugar liminar. Localizar-se no último andar do hospital traz uma carga simbólica expressiva ao CTI. A especialidade, seus representantes humanos e tecnológicos representam o "topo", o "suprasumo", o "ponto vital", o "coração do hospital".

A relação entre essa especialidade médica e as demais não é homogênea. É atividade ao mesmo tempo heróica e insana. Como a autora afirma, "é no contato com os outros setores hospitalares que o intensivista demarca mais claramente seu campo de saber e poder". O interessante é que 
ser intensivista extrapola as diferenças de status recorrentes entre as categorias profissionais da área da saúde, como a médica e a enfermagem.

$\mathrm{Na}$ intercessão entre a vida e a morte, escolhe-se investir ou desistir dos pacientes. Valores sociais, culturais e morais muitas vezes orientam as decisões tomadas pelos profissionais. A técnica pode tornar-se coadjuvante nestes casos. Ser paciente "viável" é arte complexa num mundo que oculta, rotiniza e domestica a morte, ao passo que investe intensamente no prolongamento da vida. Ser profissional que cuida dessas situações liminares é ainda mais agudo.

A classificação dos pacientes elaborada pelos integrantes das equipes do centro analisado enfatiza uma série de características que fundamentam a ciência positiva: objetificação, padronização, disciplina, método e técnica. Há crença no controle das emoções, que devem estar contidas, ou mesmo, inexistentes. Nesse livro é possível reconhecer tensões relevantes que acompanham a própria construção das Ciências Humanas em seu diálogo com as chamadas Ciências da Natureza. Na luta pela conquista do estatuto de ciência, é presença constante a tensão entre objetividade e subjetividade. No fazer antropológico, especificamente, o contato e a proximidade com o "objeto" de estudo é imprescindível, ao passo que em algum momento deste processo se torna importante certo afastamento em relação àquilo que se buscou compreender com tanta intensidade. Este movimento de aproximação e distanciamento é marcado por emoções que levam à reflexão sobre o próprio lugar do pesquisador em campo, como bem assinala a autora.

A leitura suscitou um paralelo entre o paciente ideal - viável, responsivo, anônimo e cooperativo - e o informante ideal: aquele que possibilite a abertura de portas e sirva de mediador entre os "nativos" e o pesquisador. A crença na objetividade das análises continua a perseguir nossas práticas, mesmo que se pense tratar de versões dentre tantas possíveis. Encontram-se em trabalho de campo diferentes tipos de informantes, que podem ser classificados como os "pacientes viáveis" descritos por Rachel Menezes. Em alguma medida, buscam-se informantes que reiterem o saber técnico e a competência, os responsivos, como descreve a autora. Também existem aqueles "anônimos" e "cooperativos", que não devem estar tão perto e nem tão distante que impossibilitem a análise objetiva.

Trata-se de discussão longa e complexa esta, a do fazer antropológico, e é justamente por promover tais reflexões que o livro Difíceis decisões: 
etnografia de um Centro de Tratamento Intensivo assume lugar especial, não somente para as Ciências da Saúde, mas para todos os interessados em metodologia e pesquisa social.

\section{NOTA}

- Doutora em Ciências Sociais (PPCIS/UERJ); pós-doutoranda do Centro de Estudos da Metrópole (CEM-CEBRAP). Endereço eletrônico: edlaineg@ gmail.com. 